\title{
PENGELOLAAN PENGGUNAAN PESTISIDA DALAM MENDUKUNG PEMBANGUNAN BERKELANJUTAN DI INDONESIA
}

\author{
Nugrahini Susantinah Wisnujati ${ }^{1 *}$, Suwandi S. Sangadji ${ }^{2}$ \\ ${ }^{1}$ Program Studi Magister Agribisnis, Universitas Wijaya Kusuma Surabaya \\ Jl. Dukuh Kupang XXV No.54, Dukuh Kupang, Dukuhpakis, Surabaya 60225 \\ ${ }^{2}$ Program Studi Agribisnis, Universitas Nuku \\ Jl. Sultan Mansyur Km. 244,11, Gamtufkange, Tidore 97812 \\ *Corresponding author: wisnujatinugrahini@uwks.ac.id
}

\begin{abstract}
The use of pesticides in rice production has an impact on the environment. Pesticides are chemicals used to kill or control pests. The use of pesticides carries some risks, but farmers are used to using pesticides. However, the use of pesticides may lead to the contamination of groundwater. Therefore, the research question in this study was whether there any differences in rice production before and after pesticide reduction in Indonesia. This study aimed to analyze the difference between rice production before and after pesticide reduction in Indonesia. The secondary data in this study were rice production data from FAO. Data from 1968 to 1992 were data about rice production before reducing pesticide use in Indonesia, while data from 1993 to 2017 were data about rice production after reducing pesticide use in Indonesia. The applied data analysis was paired sample t-test using SPSS 25. The results indicated that there is a significant difference between rice production before and after reducing pesticide use in Indonesia.
\end{abstract}

Keywords: rice, sustainable development, pesticide, production

\begin{abstract}
Abstrak: Penggunaan input produksi beras seperti pestisida akan berdampak pada lingkungan, pestisida adalah suatu bahan kimia yang digunakan membunuh atau mengendalikan hama. Penggunaan pestisida membawa beberapa resiko, akan tetapi petani sudah terbiasa menggunakan pestisida. Penggunaan pestisida dapat menimbulkan terjadinya pencemaran air tanah oleh suatu kontaminan. Rumusan masalah penelitian adalah apakah terdapat perbedaan produksi beras sebelum pengurangan pestisida di Indonesia dengan produksi beras sesudah pengurangan pestisida di Indonesia, tujuan penelitian menganalisis perbedaan produksi beras sebelum pengurangan pestisida di Indonesia dengan produksi beras sesudah pengurangan pestisida di Indonesia. Penelitian ini menggunakan data sekunder yakni dari FAO, dari tahun 1968 sampai dengan tahun 1992 untuk data produksi beras sebelum pengurangan penggunaan pestisida di Indonesia dan data pengurangan penggunaan pestisida dari tahun 1993 sampai dengan 2017. Analisis yang digunakan adalah analisis paired sample t-test, menggunakan software SPSS versi 25. Hasil penelitian menunjukkan terdapat perbedaan yang signifikan antara produksi beras sebelum pengurangan pestisida di Indonesia (SB) dengan sesudah pengurangan penggunaan pestisida di Indonesia (SD).
\end{abstract}

Kata kunci: beras, pembangunan berkelanjutan, pestisida, produksi

\section{PENDAHULUAN}

Sejak 1960-an, penduduk di dunia meningkat lebih dari dua kali lipat dan produksi pertanian perorang hanya meningkat sepertiganya saja. Tetapi pertumbuhan produksi telah membayar biaya yang tidak nampak yang sangat besar akibat dari penggunaan pestisida. Penggunaan 
pestisida yang berdampak pada meluasnya kerusakan ekologi yang sangat besar dan insiden keracunan masyarakat yang tinggi. Selain itu juga berdampak pada kesehatan yang kronis (Pretty, 2012)

Sebelum pengurangan penggunaan pestisida pada tahun 1993, penggunaan pestisida di Indonesia sangat mengkhawatirkan. Pestisida kimia merupakan sarana pengendalian Organisme Pengganggu Tanaman (OPT) yang paling banyak digunakan oleh petani di Indonesia $(95,29 \%)$ karena efektif, mudah digunakan dan secara ekonomi menguntungkan (Balingtan, 2013). Hasil penelitian pestisida pada petani kakao pada tahun 2011 di semua sentra produksi kakao di Indonesia mayoritas (95\%) petani kakao di Indonesia menggunakan pestisida dalam budidaya kakaonya.

Penggunaan pestisida juga

menguntungkan seperti di Amerika Latin yang menunjukkan bahwa dengan menggunakan pestisida dapat meningkatkan hasil hingga $40 \%$ pada tanaman kakao. Penggunan pestisida oleh petani di Pakistan dapat menaikkan hasil 33\% pada tanaman tebu. Berdasarkan catatan dari FAO penggunaan pestisida dapat menyelamatkan hasil $50 \%$ pada tanaman kapas (Fitriadi dan Putri, 2016)

Setelah muncul isu lingkungan hidup di sektor pertanian, yakni adanya Revolusi Hijau pada akhir 1960-an. Di antara masalah lingkungan yang dominan di lahan pertanian, ada tiga yaitu: 1) dampak penggunaan sarana input produksi terhadap produksi pertanian dan lingkungan, 2) dampak sistem pertanian terhadap emisi gas rumah kaca, dan 3) dampak kegiatan industri dan perluasan perkotaan di lahan pertanian (Las et al., 2006)

Penggunaan sarana input seperti pestisida akan berdampak pada lingkungan. Pestisida adalah suatu bahan kimia yang digunakan membunuh atau mengendalikan hama. Setiap penggunaan pestisida membawa beberapa resiko yang terkait. Penggunaan pestisida oleh petani sudah menjadi kebiasaan. Penggunaan pestisida yang memiliki kandungan bahan aktif akan menimbulkan kemungkinan terjadinya pencemaran air tanah oleh suatu kontaminan (Arif, 2015). Pertanian sebagai kegiatan manusia (antropogenik) akan berdampak pada meningkatnya emisi Gas Rumah Kaca, peningkatan emisi gas rumah kaca akan menyebabkan perubahan iklim (climate change), yakni kondisi beberapa unsur iklim yang magnitude dan atau intensitasnya cenderung berubah atau menyimpang dari dinamika dan kondisi rata-rata. (Sudarma dan As-syakur, 2018). Indonesia adalah negara agraris, jumlah penduduknya paling tinggi dibandingkan dengan negara ASEAN lainnya, seperti Brunai Darussalam, Malaysia dan masyarakatnya sangat tergantung pangan beras. Maka agar Indonesia mampu menjadi negara yang memiliki ketahanan pangan, perlu dianalisis bagaimana ketahanan pangan di Indonesia dengan dikuranginya penggunaan pestisida.

Keamanan pangan dinyatakan sebagai tidak adanya kelaparan, terdapat ketersediaan dari pasokan makanan, akses, kecukupan, pemanfaatan, keamanan (Nkrumah, 2018) Negara negara ASEAN berkomitmen untuk mampu menjadi basis beras, lalu bagaimana kecukupan pangan di dalam negeri. Setiap negara juga menyepakati pengurangan penggunaan pestisida yang tertuang dalam Sustainable Development Goals (SDGs), lantas bagaimana kemampuan Indonesia dalam merealisasikan kesepakatan tersebut guna mendukung pembangunan berkelanjutan. Indonesia sebagai negara yang telah sepakat pada Pembangunan Berkelanjutan. Konsep pembangunan berkelanjutan telah menjadi kesepakatan dunia. Pada tahun 2000 para pemimpin dunia menetapkan Tujuan Pembangunan Milenium (MDGs) sebagai agenda kolektif untuk meningkatkan kehidupan masyarakat di seluruh dunia dengan berakhirnya MDGs, pada tahun 2015, dilanjutkan (SDGs), sebagai penerus MDGs. Pelaksanaan agenda pembangunan nasional SDGs selama 2010-2017, Gas rumah kaca (GRK) telah berkurang sebesar $22,5 \%$ dari baseline akumulatif sebesar 13 miliar ton CO2e, dan intensitasnya sebesar $27 \%$ dari baseline sebesar 560 ton $\mathrm{CO} 2 \mathrm{e}$ per miliar rupiah (United Nations, 2019).

Menyikapi permasalahan diatas, maka rumusan masalah yang diajukan yaitu apakah terdapat perbedaan produksi beras sebelum pengurangan pestisida di Indonesia dengan produksi beras sesudah pengurangan pestisida di Indonesia. Adapun tujuan penelitian ini adalah 1) pengelolaan penggunaan pestisida di Indonesia, dan 2) menganalisis perbedaan produksi beras sebelum pengurangan pestisida 
di Indonesia dengan produksi beras sesudah pengurangan pestisida di Indonesia.

\section{METODE PENELITIAN}

\section{Data Penelitian}

Penelitian ini menggunakan data sekunder yakni data dari FAO (FAO, 2020). Data produksi sebelum pengurangan pestisida di Indonesia menggunakan data dari tahun 1968 sampai dengan tahun 1992, untuk data produksi beras sebelum pengurangan pestisida di Indonesia menggunakan data tahun 1993 sampai dengan tahun 2017.

\section{Analisis Data}

Analisis yang digunakan adalah analisis t-test independent, menggunakan software SPSS versi 25. Adapun analisis membandingkan dua situasi yakni produksi sebelum pengurangan pestisida dan produksi sesudah pengurangan pestisida. Uji t-test independent adalah uji homogenitas, yakni suatu uji yang dilakukan untuk mengetahui bahwa dua atau lebih kelompok data sampel berasal dari populasi yang memiliki varians sama (homogen). Uji homogenitas dapat dilakukan dengan uji levene, fisher atau uji bartlett. Pengujian ini merupakan persyaratan sebelum melakukan pengujian lain, misalnya t-test dan Anova. Pengujian ini digunakan untuk meyakinkan bahwa kelompok data memang berasal dari sampel yang sama. Pada penelitian ini dihipotesiskan bahwa terdapat perbedaan produksi beras sebelum pengurangan pestisida.

\section{Penentuan Homogenitas Data}

Data yang dilakukan pengujian dikatakan homogen berdasarkan nilai signifikansinya.

- Nilai signifikansi $(\mathrm{p}) \geq 0,05$ menunjukkan kelompok data berasal dari populasi yang memiliki varians yang sama (homogen).

- Nilai signifikansi (p) $<0,05$ menunjukkan masing-masing kelompok data berasal dari populasi dengan varians yang berbeda (tidak homogen).

\section{HASIL DAN PEMBAHASAN}

\section{Keragaman Produksi Beras Indonesia}

Indonesia sebagai negara yang menandatangani perjanjian Masyarakat Ekonomi ASEAN (MEA) atau yang lebih dikenal dengan $A S E A N$ Economic Community (AEC) bersama dengan sembilan negara lain berupaya mewujudkan basis produksi dan menjadi pasar tunggal (Nugrahini, 2018). Konsep ini tentunya harus didorong dengan peningkatan produksi khususnya tanaman pangan seperti beras.

Hasil produksi beras didukung oleh penggunaan input produksi seperti pestisida, Salah satu penelitian menunjukkan bahwa faktor-faktor yang berpengaruh terhadap produksi pada usahatani padi sawah adalah lahan, benih, pupuk, pestisida, dan tenaga kerja (Yusuf, 2011).

Indonesia tercatat sebagai negara dengan pengurangan penggunaan pestisida paling signifikan. Indonesia sudah mengalami pengurangan mulai tahun 1992 dan konstan penggunaannya sebanyak 1.597 ton pertahun.

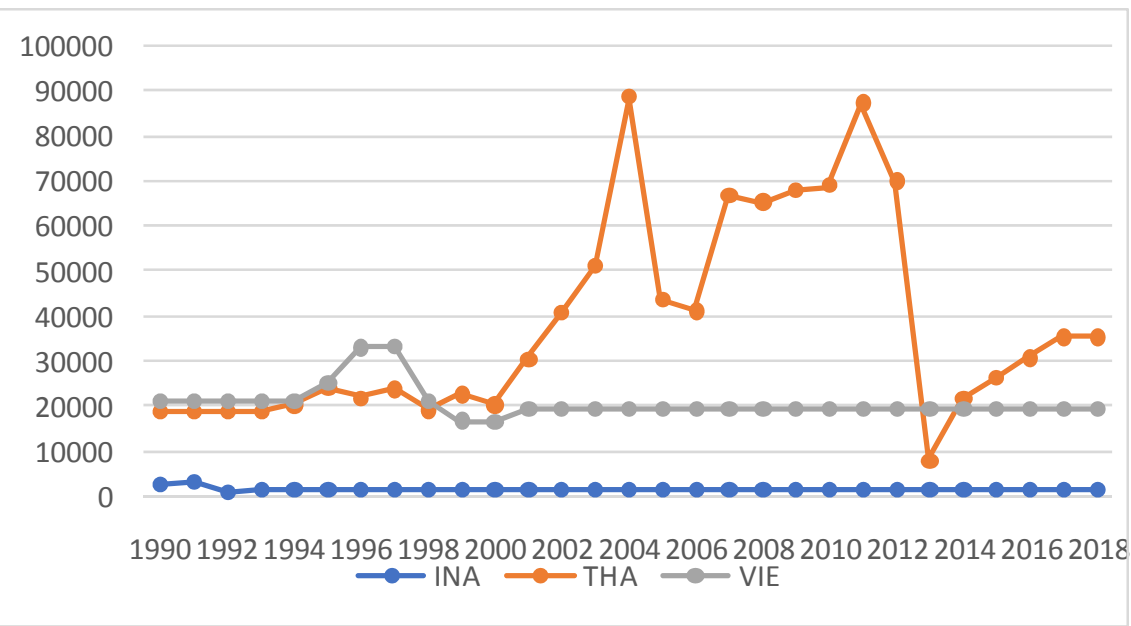

Gambar 1. Penggunaan pestisida di Indonesia, Thailand dan Vietnam Sumber : FAOSTAT, 2020 
Wisnujati, N. S., Sangadji, S. S. : Pengelolaan Penggunaan Pestisida dalam ...

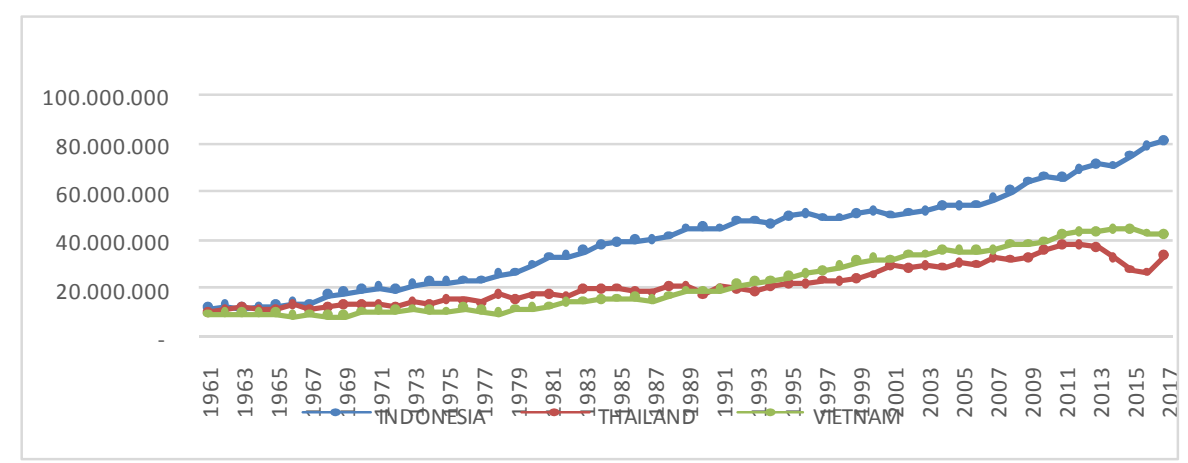

Gambar 2. Produksi beras di Indonesia, Thailand dan Vietnam Sumber : FAO,2020

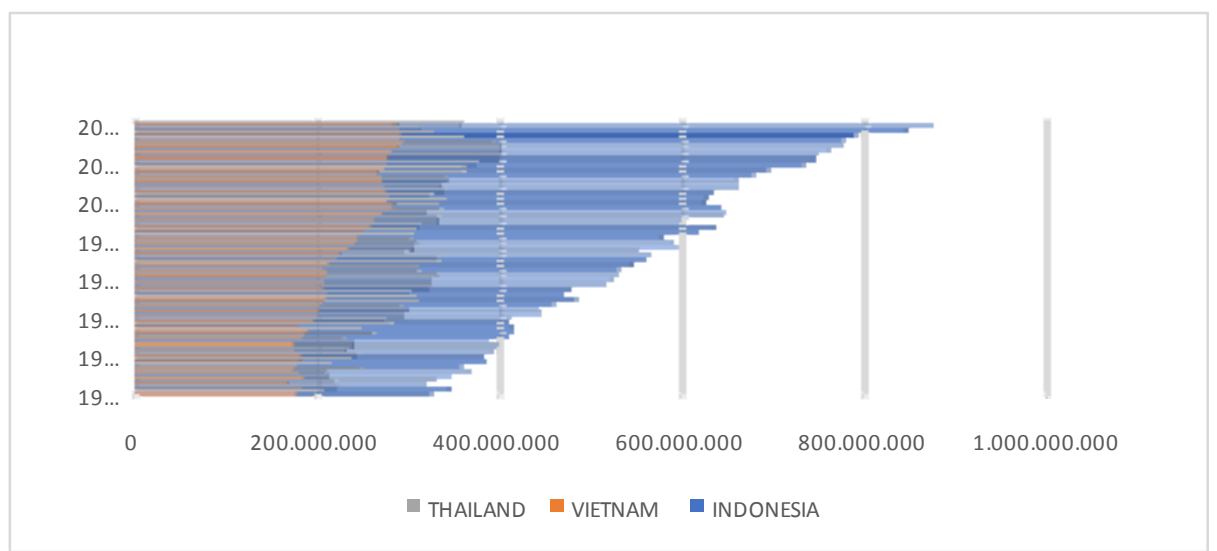

Gambar 3 Emisi $\mathrm{CO}_{2}$ di Indonesia, Thailand dan Vietnam

Sumber : FAO, 2020

Disusul Vietnam yang mulai mengurangi penggunaan pestisida pada tahun 2001, penggunaan konstan pada kisaran 19.154 ton, di bandingkan dengan Negara Thailand yang masih tinggi penggunaannya, penggunaan pestisida paling tinggi di Thailand adalah 88.548 ton pada tahun 2004 , dan relatif tetap tinggi sampai dengan tahun 2018.

Produksi beras negara Indonesia paling unggul setelah tahun 1968 , hal ini dapat dilihat pada Gambar 1. Tahun 1961 sampai dengan tahun 1967 produksi ketiga negara ASEAN yakni Indonesia (INA), Thailand (THA) dan Vietnam (VIE) tersebut relatif sama. Upaya peningkatan produksi di negara Indonesia dengan menerapkan Program pengembangan pertanian yang dikenal dengan Revolusi Hijau. Program ini bertujuan untuk peningkatan hasil pertanian, khususnya padi. Program ini yang membuat Indonesia mampu melakukan swasembada beras pada tahun 1979 dengan produksi sebesar 26.282.656 ton dan pada tahun 1985 produksi beras sebesar 39.032.944 ton. Pada dua tahun tersebut Indonesia berhasil meningkatkan produksi pangan sampai $49 \%$.

\section{Pencemaran Lingkungan Dari Emisi $\mathrm{CO}_{2}$}

Emisi $\mathrm{CO}_{2}$ di Indonesia paling tinggi dibandingkan dengan negara lain di ASEAN, seperti Thailand dan Vietnam. Sektor pertanian mempunyai kontribusi terjadinya kerusakan lingkungan. Setiap penggunaan pestisida membawa beberapa resiko yang terkait. Penggunaan pestisida memiliki kandungan bahan aktif pada suatu lingkungan akan menimbulkan kemungkinan terjadinya pencemaran air tanah oleh suatu kontaminan (Arif, 2015).

Pada Gambar 3, garis biru menunjukkan Emisi $\mathrm{CO}_{2}$ di Indonesia paling tinggi dibandingkan dengan negara Vietnam dan Thailand. Pada penelitian menyatakan Sawah dianggap sebagai sumber dari gas rumah kaca, terutama metana $\left(\mathrm{CH}_{4}\right)$ dan karbon dioksida $\left(\mathrm{CO}_{2}\right)$ (Mulyadi dan Wihardjaka 2014), emisi $\mathrm{CO}_{2}$ lebih berbahaya daripada metana. Temuan menarik pada data $\mathrm{FAO}$, adalah produksi beras Vietnam lebih tinggi di bandingkan dengan Thailand tetapi emisi $\mathrm{CO}_{2}$ nya lebih rendah daripada Thailand. Sehingga pengenggunaan pestisida perlu pengawasan pemerintah. Setiap 
kebijakan pemerintah untuk pembangunan sebaiknya melihat dampaknya pada kesehatan masyarakat (Johnston et al., 2019), dan kesepakatan SDGs pada laporan (United Nations, 2012) menunjukkan bahwa beberapa penelitian telah menyimpulkan sistem pertanian global saat ini sudah melampaui batas aman untuk perubahan tata guna lahan, konsekuensinya seperti meningkatnya gas rumah kaca di atmosfer meningkat.

\section{Pengelolaan Penggunaan Pestisida di Indonesia}

Pengelolaan penggunaan pestisida adalah upaya yang dilakukan petani sebelum, selama dan sesudah penggunaan pestisida, mulai dari penyemprotan, percikan, perlakuan terhadap sisa, penyimpanan, kelengkapan APD dan pembuangan kemasan pestisida. Pestisida yang paling sering digunakan di Indonesia adalah jenis dithiocarbamates, pyrethroids dan organophosphates. Menurut Organisasi Kesehatan Dunia (WHO) Sekitar 80\% penyemprotan, pestisida kategori II ini, cukup berbahaya digunakan. Tindakan perlindungan dan penanganan yang aman jarang diamati, sedangkan merokok dan minum selama penyemprotan sering dilakukan. Petani yang mengenakan baju lengan panjang dan penutup kepala lebih jarang menunjukkan gejala kesehatan. Selain itu, petani yang kontak kulit dengan larutan semprotan saat mengukur atau mencampur (tidak termasuk tangan), yang memakai pakaian basah (kulit terpapar pestisida), dan yang merokok dan mengucek mata saat penyemprotan menunjukkan lebih banyak gejala (Sekiyama et al., 2007).

Karena begitu besar bahaya yang ditimbulkan dari penggunaan pestisida maka negara-negara diseluruh dunia berpikir ulang untuk menggunakan pestisida. Salah satu alasan pengelolaan penggunaan pestisida di Indonesia, karena Indonesia pada tahun 2000 telah sepakat Bersama 146 kepala negara di Dunia menandatangi Millenium Development
Goals (MDGS) atau pembangunan millennium (Sachs dan McArthur, 2005). Setelah MDGs berakhir dilanjutkan dengan Sustainable Development Goals (SDGs), upaya pengurangan penggunaan pestisida di Indonesia di mulai pada tahun 1993. Pengurangan penggunaaan pestisida di Indonesia dibarengi dengan upaya mengelola lingkungan dengan teknologi. Teknologi yang diterapkan melalui Sekolah Lapang Pengendalian Hama Terpadu (SLPHT) Penerapan SLPHT hampir sama untuk setiap kabupaten. Pada periode yang sama, penggunaan pestisida pada padi mengalami penurunan. Penurunan penggunaan pestisida secara drastis terjadi pada awal periode. Jumlah petani yang menderita keracunan adalah sebanyak 55 orang $(63,96 \%)$ dan yang tidak menderita keracunan adalah sebanyak 31 orang $(36,04 \%)$. Petani perlu mengurangi paparan pestisida dengan cara memakai APD secara lengkap dan benar, menyimpan pestisida dengan baik dan benar, mengurangi lama kerja, tidak bekerja di tempat yang sama ketika suami/ayah sedang menyemprotkan pestisida, karena bahaya pestisida begitu besar pengaruhnya terutama terhadap kesehatan dalam jangka panjang, perlu melakukan pemantauan kejadian Intoksikasi (keracunan) dalam kegiatan pertanian untuk meningkatkan kesadaran petani pada bahaya pestisida dan bagaimana cara melindungi diri dari paparan pestisida (Yuniastuti, 2018).

Menurut penelitian permintaan pestisida pada padi dipengaruhi oleh serangan hama, harga relatif pestisida, introduksi teknologi PHT, dan luas tanam. Pada saat harga relatif naik dan dilaksanakan pengenalan teknologi PHT pada masyarakat petani berdampak pada penurunan penggunaan pestisida, sebaliknya apabila terdapat kenaikan serangan hama dan penggunaan luas tanam yang besar akan menaikkan penggunaan pestisida. Sumbangan teknologi PHT pada penurunan penggunaan pestisida sebesar 20\% sedangkan kontribusi

Tabel 1. Uji normalitas

\begin{tabular}{lllllll}
\hline \multicolumn{7}{c}{ Test of Normality } \\
\hline & \multicolumn{7}{l}{ Kolmogorov-Smirnov } & \multicolumn{5}{l}{ Shapiro Wilk } & \\
SD & Statistik & df & Sig & Statistik & df & Sig \\
SB & 0,171 & 17 & 0,200 & 0,918 & 17 & 0,137 \\
\hline
\end{tabular}

Sumber : Analisis Data Sekunder, 2020 
perubahan harga pada penurunan penggunaan pestisida sebesar $80 \%$. Kebijakan harga mempunyai dampak lebih besar, tidak berarti bahwa kebijakan ini lebih efektif dibanding dengan introduksi teknologi PHT (Mariyono, 2006).

Pemerintah perlu lebih meningkatkan upaya pengelolaan penggunaan pestisida dengan pelaksanaan SLPTHT, petani perlu menggunakan APD dan tentu saja peningkatan pengetahuan petani tentang bahaya pestisida, baik jangka pendek dan jangka panjang.

\section{Perbedaan Produksi Beras Sebelum Pengurangan Pestisida Dengan Produksi Beras Sesudah Pengurangan Pestisida di Indonesia}

\section{Uji Normalitas}

Uji normalitas digunakan sebagai syarat atau asumsi dari berbagai uji parametrik, misalnya uji regresi linear, uji Anova, uji Manova, uji independent $t$-test, uji paired t-test dan berbagai uji lainnya, baik analisis multivariat ataupun univariat.

Sebagai syarat uji parametrik, maka apabila asumsi normalitas tidak terpenuhi atau dengan kata lain tidak berdistribusi normal atau terima H1, maka peril dilaksanakan perlakuan sesuai analisis hipotesis yang digunakan. Apabila asumsi normalitas tidak terpenuhi pada uji independent t-test, maka kita bisa menggunakan uji alternatif dengan uji non parametrik.

Pada uji normalitas pada Tabel 1 menunjukkan bahwa nilai signifikansi pada uji kolmogorov-Smirnov adalah 0,2 untuk produksi sebelum pengurangan pestisida di Indonesia (SB), 0,13 untuk produksi sesudah pengurangan penggunaan pestisida di Indonesia (SD) 0,7 atau $p>0,05$, artinya berdasarkan uji normalitas kolmogorov-Smirnov data terbukti berdistribusi normal.

Pada uji Shapiro-Wilk menunjukkan nilai 0,137 untuk produksi sebelum pengurangan pestisida di Indonesia (SB) 0,94 dan 0,91 untuk produksi sesudah pengurangan penggunaan pestisida di Indonesia (SD)

Uji Beda Produksi Beras Sebelum dan sesudah Pengurangan Penggunaan Pestisida Analisis perbedaan produksi setelah pengurangan penggunakan pestisida di negara
Indonesia dengan produksi sebelum pengurangan penggunakan pestisida di negara Indonesia menggunakan analisis Levene's Test For Equality of Variances. Berdasarkan hasil analisis diketahui Levene's Test For Equality of Variances sebesar 0,927 >0,05 menunjukkan varian data produksi sebelum pengurangan penggunaan pestisida di Indonesia (SB) sama dengan data produksi sesudah pengurangan penggunaan pestisida di Indonesia (SD). Sehingga analisis data menggunakan nilai Equal variance assumed. Dari hasil signifikansi, menunjukkan bahwa Ho ditolak, berarti $\mathrm{Ha}$ diterima, artinya ada perbedaan signifikan antara produksi sebelum pengurangan pestisida di Indonesia (SB) dengan sesudah pengurangan penggunaan pestisida di Indonesia (SD). Hasil uji beda dapat dilihat pada Tabel 2.

Nilai mean difference yang diperoleh sebesar -28.131.290,8 merupakan selisih antara produksi sesudah pengurangan pestisida di Indonesia (SD) dengan sebelum pengurangan penggunaan pestisida di Indonesia (SN), pada taraf signifikansi 95\%.

\section{Pembahasan}

Produksi beras Vietnam lebih tinggi daripada Thailand, tetapi tingkat emisi $\mathrm{CO}_{2}$ nya lebih rendah, artinya penggunaan pestisida dapat dikelola secara benar, hal ini seperti penelitian (Sukiyono, 2016) bahwa perbedaan tingkat efisiensi teknis di masyarakat petani menunjukkan terdapat tingkat penguasaan dan aplikasi teknologi berusahatani yang berbeda. Tingkat penguasaan teknologi yang berbeda tersebut disebabkan oleh karakteristik petani, seperti tingkat pendidikan dan umur, tetapi ada faktor yang juga berpengaruh yakni faktor di luar atribut petani seperti kurangnya pelaksanaan penyuluhan pada petani. Hasil penelitian menunjukkan bahwa faktor yang berpengaruh signifikan terhadap inefisiensi teknis padi sawah adalah kemampuan manajerial yang dianalisis dari umur, pendidikan, dan pengalaman menjalankan usahatani. Bertambahnya umur, meningkatnya pendidikan, serta bertambahnya pengalaman, cenderung dapat meningkatkan inefisiensi teknis petani. Sedangkan ukuran keluarga tidak berpengaruh signifikan terhadap inefisiensi teknis. Penelitian ini menunjukkan bahwa 
Wisnujati, N. S., Sangadji, S. S. : Pengelolaan Penggunaan Pestisida dalam ...

Tabel 2. Uji beda penggunaan pestisida dan pengurangan penggunaan pestisida di Indonesia

\begin{tabular}{|c|c|c|c|c|c|c|c|c|}
\hline \multicolumn{9}{|c|}{ Independent Samples Test } \\
\hline & & \multicolumn{2}{|c|}{$\begin{array}{c}\text { Levene's Test } \\
\text { for Equality of } \\
\text { Variances }\end{array}$} & \multicolumn{5}{|c|}{ t-test for Equality of Means } \\
\hline & & $\mathrm{F}$ & Sig. & $\mathrm{t}$ & df & Sig. (2-tailed) & $\begin{array}{c}\text { Mean } \\
\text { Difference }\end{array}$ & $\begin{array}{l}\text { Standard } \\
\text { Error } \\
\text { Difference }\end{array}$ \\
\hline \multirow[t]{2}{*}{ Produksi } & $\begin{array}{l}\text { Equal } \\
\text { variances } \\
\text { assumed }\end{array}$ & 0,008 & 0,927 & $-9,6$ & 48 & 0,000 & $-28131290,8$ & 2922359,2 \\
\hline & $\begin{array}{l}\text { Equal } \\
\text { variances } \\
\text { not } \\
\text { assumed }\end{array}$ & & & $-9,6$ & 47,9 & 0,000 & $-28131290,8$ & 2922359,2 \\
\hline
\end{tabular}

kemampuan manajerial sebetulnya dapat mendukung efisiensi penggunaan pestisida.

Selain negara Indonesia, 146 negara di dunia sepakat untuk mencapai SDGS, maka beberapa tahun terakhir jutaan petani di seluruh dunia mengurangi penggunaan pestisida, beralih pada pengembangan alternatif yang lebih murah dan lebih aman. The Pesticide Detox mengeksplorasi potensi penghentian penggunaan pestisida berbahaya dan pentahapan alternatif hemat biaya. Sudah saatnya untuk memulai detoksifikasi pestisida dan bergerak menuju pertanian yang lebih berkelanjutan (Pretty, 2012).

Di Wilayah Eropa terdapat Undangundang Masyarakat Eropa (EC) yang telah membatasi ketersediaan zat aktif pestisida yang digunakan dalam produk perlindungan tanaman yang efektif.

Masyarakat Eropa memiliki petunjuk penggunaan pestisida no. 91/414/ EEC yang memperkenalkan prinsip penilaian risiko bahan aktif di kandungan pestisida, tentang bahaya, toksisitas intrinsik bahan aktif, potensi bahaya yang akan terjadi. Meskipun akan berdampak signifikan pada ketersediaan pestisida dalam jangka menengah hingga panjang, peraturan tentang kualitas air (Water Framework Directive 2000/60/EC dan Drinking Water Directive 1998/83/EC) berpotensi untuk membatasi penggunaan pestisida lebih cepat, karena kekhawatiran tentang kesehatan masyarakat dan biaya ekonomi penghapusan pestisida dari air meningkat. Alasan ini selanjutnya akan mengurangi ketersediaan bahan aktif pestisida yang efektif, yang secara langsung memengaruhi perlindungan tanaman dan meningkatkan ketahanan pestisida dalam populasi hama dan penyakit. Selain itu, persyaratan kualitas air juga dapat berdampak pada zat aktif penting yang digunakan dalam perlindungan tanaman di Irlandia. Tantangan masa depan untuk pertanian di Irlandia adalah mempertahankan produksi dan profitabilitas dengan menggunakan masukan pestisida yang dikurangi dalam kerangka pengelolaan hama terpadu (Jess et al., 2014).

Melihat hasil analisis bahwa pengurangan penggunaan pestisida berdampak pada produksi beras di Indonesia, artinya bahwa produksi beras tetap meningkat walaupun pemerintah menerapkan kebijakan mengurangi pestisida, maka selayaknya pemerintah tetap melaksanakan kebijakan pengurangan penggunaan pestisida, Langkah yang ditempuh dengan meningkatkan pengetahuan petani, hal ini karena hasil penelitian (Yuantari et al., 2013) menyatakan bahwa Peningkatan pengetahuan petani lebih efektif dilaksanakan dengan pemberdayaan petani. Petani dapat menyadari pentingnya cara penggunaan pestisida serta memahami sendiri bahaya penggunaan pestisida. Peningkatan pengetahuan petani dapat dilaksanakan dengan pelatihan pembuatan pestisida organik (Astuti dan Widyastuti, 2016).

\section{KESIMPULAN}

Pengelolaan penggunaan pestisida perlu dilakukan dengan menerapkan SLPHT, peningkatan pengetahuan petani dan penggunaan APD. Terdapat perbedaan 
produksi beras sebelum pengurangan pestisida di Indonesia dengan produksi beras sesudah pengurangan pestisida di Indonesia.

\section{DAFTAR PUSTAKA}

Arif, A. (2015). Pengaruh bahan kimia terhadap penggunaan pestisida lingkungan. JF FIK UINAM, 3(4), 134-143.

Astuti, W., \& Widyastuti, C. R. (2016). Pestisida organik ramah lingkungan pembasmi hama tanaman sayur. Rekayasa, 14(2), 115-120. https://doi. org/10.15294/rekayasa.v14i2.8970.

Mariyono, J. (2006). Kontribusi teknologi pengendalian hama terpadu pada penurunan penggunaan pestisida: Kasus produksi padi di Yogyakarta. Jurnal Matematika Sains Dan Teknologi,7(2), 1285-138.

FAO. (2020). FAO publications catalogue 2020. Retrieved from https://doi.org/10. 4060/cb1512en.

Fitriadi, B. R., \& Putri, A. C. (2016). Metodemetode pengurangan residu pestisida pada hasil pertanian. Jurnal Rekayasa Kimia \& Lingkungan, 11(2), 61-71. https://doi.org/10.23955/rkl.v11i2.4950.

Jess, S., Kildea, S., Moody, A., Rennick, G., Murchie, A. K., \& Cooke, L. R. (2014). European Union policy on pesticides: Implications for agriculture in Ireland. Pest Management Science, 70(11), 16461654. https://doi.org/10.1002/ps.3801.

Johnston, L., Davison, C., Lkhagvasuren, O., \& Janes, C. R. (2019). Assessing the effects of a Canadian-Mongolian capacity building program for health and environmental impact assessment in the mining sector. Environmental Impact Assessment Review, 76, 61-68. https:// doi.org/10.1016/j.eiar.2019.01.002.

Las, I., Subagyono, K., Setiyanto, A. P., Besar, B., Dan, P., Sumberdaya, P., \& Pertanian, L. (2006). Isu dan pengelolaan lingkungan dalam revitalisasi pertanian.
Jurnal Penelitian Dan Pengembangan Pertanian, 25(3), 173-193.

Nkrumah, B. (2018). Edible backyards: climate change and urban food (in)security in Africa. Agriculture \& Food Security, 7(1). https://doi.org/10.1186/s40066018-0196-y.

Pretty, J. N. (2012). The Pesticide Detox: Towards a More Sustainable Agriculture. Oxford, England: Routledge.

Sachs, J. D., \& McArthur, J. W. (2005). The millennium project: A plan for meeting the Millennium Development Goals. Lancet, 365(9456), 347-353. https://doi. org/10.1016/S0140-6736(05)70201-4.

Sekiyama, M., Tanaka, M., Gunawan, B., Abdoellah, O., \& Watanabe, C. (2007). Pesticide usage and its association with health symptoms among farmers in rural villages in West Java, Indonesia. Environmental Sciences : $A n$ International Journal of Environmental Physiology and Toxicology, 14 Suppl, 23-33.

Sudarma, I. M., \& As-syakur, A. R. (2018). Dampak perubahan iklim terhadap sektor pertanian di Provinsi Bali. SOCA: Jurnal Sosial Ekonomi Pertanian, 12(1), 87-98. https://doi.org/10.24843/soca.2018.v12.i 01.p07.

Sukiyono, K. (2016). Faktor penentu tingkat efisiensi teknik usahatani cabai merah di Kecamatan Selupu Rejang, Kabupaten Rejang Lebong. Jurnal Agro Ekonomi, 23(2), 176-190. https://doi.org/10.21082/ jae.v23n2.2005.176-190.

United Nations. (2019). Empowering people and ensuring inclusiveness and equality Report of the Secretary-General. Retrieved from https://digitallibrary.un. org $/ \mathrm{record} / 3805750 ? \ln =$ en

United Nations. (2012). Back to our Common Future: Sustainable Development in the 21st Century (SD21) project. Retrieved 
Wisnujati, N. S., Sangadji, S. S. : Pengelolaan Penggunaan Pestisida dalam ...

from http://sustainabledevelopment.un. org/content/documents/UNDESA backD ESA_Back_Common_Future_En.pdf.

Yuantari, M. G. C., Widiarnako, B., \& Sunoko, H. R. (2013). Tingkat pengetahuan petani dalam menggunakan pestisida (studi kasus di Desa Curut Kecamatan Penawangan Kabupaten Grobogan). Prosiding Seminar Nasional Pengelolaan Sumberdaya Alam dan Lingkungan 2013.

Yuniastuti, A. (2018). Hubungan masa kerja, lama menyemprot, jenis pestisida, penggunaan APD dan pengelolaan pestisida dengan kejadian keracunan pada petani di Brebes. Public Health Perspective Journal, 2(2), 117-123.

Yusuf, M. N. (2011). Efisiensi teknis usahatani padi sawah (studi kasus pada kelompok tani Raksa Bumi III Desa Sindangsari Kecamatan Kawali Kabupaten Ciamis. Mimbar Agribisnis: Jurnal Pemikiran Masyarakat Ilmiah Berwawasan Agribisnis, 1(1), 85-94. 